\author{
Aneta Pawłowska \\ Department of Art History \\ University of Łódź \\ aneta.pawlowska@uni.lodz.pl
}

\author{
Anna Wendorff \\ Department of Spanish Philology \\ University of Łódź \\ anna.wendorff@uni.lodz.pl
}

\title{
PARTICIPATORY ART, NEW MEDIA AND CONVERGENCE ART BASED ON THE EXAMPLE OF LA FURA DELS BAUS GROUP
}

\begin{abstract}
His [artist] art is an amazing act of primordial mimesis, in which he unlearns or suspends ordinary symbolizations of experience - one might say the inhibitory symboliza tions of experience that make it ordinary - in order to display its primordial givenness. ${ }^{1}$
\end{abstract}

Es teatro lo que hace "La Fura"? [Is theatre what La Fura does?] ${ }^{2}$

\begin{abstract}
The article attempts to present various categories of activities related to participatory art that we can find in the extensive artistic output of the Catalan group named La Fura dels Baus. Ever since it was established in 1979, the group has been presenting a wide variety of forms: open-air events, dramatic plays, operas, and performances. It uses typically theatrical techniques, emphasizing especially quasi-religious experiences and experiments originating from mythical prehistory of the stage art and newer group techniques (happening, techniques develo-
\end{abstract}

D. Kuspit, The Cult of the Avant-Garde Artist, Cambridge University Press, Cambridge 1993, p. 5.

2 J. Martínez, La Fura dels Baus, "La Nueva España” 1994, p. 38. 
ped by groups of the contestation period). The article discusses such shows as: Accions (1983), Suz/O/Suz (1985), Noun (1990), Manes and MTM (both 1996), as well as XXX (2001). Special attention is paid to acquisition and adaptation of Artaud's concept of "Theatre of Cruelty" in relation to the group's activities, which at the same time are analysed from the perspective of audience participation in performances forced by artistic means.

Keywords: La Fura dels Baus, participation, Theatre of Cruelty, spectacle, audience.

\section{Relation, participation and sacrum in contemporary art}

According to a culture theoretician, Ryszard W. Kluszczyński, the avantgarde revolution had the following background: "art and artist radically separated from everyday life; positively valued art, everyday life - negated. Split between art and everyday life was accompanied by deepening distance of the former from the sphere of sacrum. Art gains autonomy: its own «aesthetic sacrum»". ${ }^{3}$ It is difficult to disagree with this thesis, which naturally resulted in extreme institutionalization of art and its total separation from life. Institutionalization related to the process of autonomization of individual fields of art, legislation and knowledge broke the unity of many areas of human activity with everyday life. Which, in turn, led to so-called institutional critique, ${ }^{4}$ contesting all conservative social institutions. This issue was frequently discussed in the 1960s and 1970s by such artists and theoreticians as Michael Asher, Robert Smithson, Daniel Buren, Hans Hake and Marcel Broodthaers, who initiated struggle against the concept of "art" as a distinguished field of human activity, practiced by the selected, for the selected and in a strictly defined space. This first wave of institutional critique was primarily influenced by the Frankfurt School and the circle of Situationists and Guy Debord, ${ }^{5}$ and it concerned negation of traditional divisions (into art and non-art, into a museum and non-museum, into an artist and audience). As a natural reaction, many artists associated with various fields of art started to strive after bridging the gap between art and audience, thanks to which they wanted to regain the lost audience and achieve artistic effectiveness. This is the moment that marks the beginning of a phenomenon

3 R. W. Kluszczyński, Awangarda - rozważania teoretyczne, Wydawnictwo Uniwersytetu Łódzkiego, Łódź 1997, p. 52.

4 Institutional critique is a critical analysis of all aspects of activities of cultural institutions. It is also a "critical study of practices, structures and methods of working in art". M. Keil, Do czego jest nam dzisiaj potrzebna krytyka instytucjonalna?, "Polish Theatre Journal" 2015, nos $1-2$, p. 3.

5 For more information see: G. Debord, Społeczeństwo spektaklu oraz Rozważania o spoteczeństwie spektaklu, transl. M. Kwaterko, Państwowy Instytut Wydawniczy, Warszawa 2006. Originally published in France as La Société du spectacle in 1967 by BuchetChastel, English translation by Donald NicholsonSmith, published by Zone Books, as The Society of the Spectacle in 1994. 
known as "participatory art". According to Claire Bishop, it can be considered "a kind of strategy through which people become material of artistic work. An artist arranges a situation and encourages its participants to behave in a certain way in the indicated place". ${ }^{6}$

\section{La Fura dels Baus and relational art ${ }^{7}$}

As it has been mentioned, contemporary artistic conventions use many means of expression to get closer to the unity between art, a sphere of sacrum and everyday life, existing in ancient and medieval times. What seems especially useful in achieving such unity on the grounds of visual arts, poetry and theatre is a concept of relational art, emphasizing that "every artistic activity expresses certain social values" 8 and a dialogical concept of participatory art.

What deserves special attention among many activities of this nature, ${ }^{9}$ the Catalan theatre and art group, La Fura dels Baus. A context of group's early performances in a form of street theatre was connected with an attempt to politicize their plays, which in a specific Spanish situation at the end of General Franco's dictatorship may be easily denoted as activities leading to expansion of democracy. It is also an attempt to get out of a situation in which, as Debord said, passive society can only be "a spectator". ${ }^{10}$ Therefore, from the moment of its creation in 1979, the group has been presenting a wide variety of forms: open-air events, dramatic plays, operas, and performances. It uses typically theatrical techniques, emphasizing especially quasi-religious experiences and experiments originating from the mythical prehistory of the stage art and newer group techniques (happening, techniques developed by groups of the contestation period, but also a method of "collective creation"). On the other hand, La

6 I. Zmyślony, Lekkie rozczarowanie. Rozmowa z Claire Bishop, "dwutygodnik.com”, http:// www.dwutygodnik.com/artykul/6460-lekkie-rozczarowanie.html [10.06.2018].

7 A term "relational art" is defined after Nicolas Bourriaud, who, using his concept to interpret the art of the 1990s as not concentrating on objects but placing interpersonal relations at the centre of its interest. Idem, Estetyka relacyjna, transl. Ł. Białkowski, MOCAK, Kraków 2012. Oryginally published in France as L'esthétique relationnelle in 1998 by Les Presses du réel.

8 Ibid., p. 19.

9 In Poland, there were such formations as student theatre or alternative theatre, whose theatrical space was used to establish non-subordinated contact between all participants of a theatrical event, which resulted in, among others, beginning of street theatre in the 1970s and radical manifestations, such as campaigns of Akademia Ruchu, undertaken in the public space and performances of OPT "Gardzienice" presented as a part of the Expeditions and Congregations. At the same time, various games with a traditional model of theatre space were also successfully carried out in institutional theatres (e.g. Dziady, directed by Konrad Swinarski, 1973).

10 A term coined by: G. Debord, Spoteczeństwo.... 
Fura dels Baus willingly (especially in later realizations) uses achievements of modern technology: the à grand spectacle machinery allowing for multiplication of means and effects.

The artists associated with the group (but also the commentators of their activities) describe their theatricality, using a term lenguaje furero (Furan language).${ }^{11}$ Although poetics of their performances is characteristic and easily recognizable, it is not free from influences, often of a historical nature. In searching interaction with mass audience, we can find echoes of Max Reinhardt's aspirations, to which we will return in a moment. In turn, longing for the showmachine makes us think of the idea of total theatre of Erwin Piscator, and a way of working with an actor and his body is not at all distant from the concept of biomechanics coined by Vsevolod Meyerhold. In realizations of La Fura dels Baus, there is also a desire to influence a spectator in a way close to the theatre of Bertolt Brecht and ideas of the The Living Theatre. ${ }^{12}$

No wonder that subsequent shows of the Catalan group have often been a reflective continuation of previous activities or have been given a final form as a result of work on subsequent versions. This was the case of the performance Accions, whose first sketch was made in early autumn 1983, but only after a few months its mature form was born. In this show, characters of the hombres de fango use violence to create real or rather hyper-real theatre. The theatre which is very effective, extremely exciting and stimulating, drawing from strength, risk and violence. Its structure contains elements of circus performances, which makes Fura close to the Roman circus. However, it is not only about a circus character in a technical and gymnastic sense. Accions had a nonfiction structure, consisting - as in a circus - of subsequent, loose parts (seven in the mature version). An analysis of these segments, their mutual relations and relationships with intra- and extra-theatrical reality led to metatheatrical reflections, since all the quest for fictional structures had to fail. According to a London theatre critic, Mick Sinclair, in Accions (1984) - the first one presented outside Spain - the group "created a kind of adventure playground for adults with fun, danger, slapstick and fantasy" ${ }^{13}$ At the same time, according to Agnieszka Sosnowska and Joanna Zielińska, it seems that as a result of an independent, slow shaping the show by actors and participating spectators we rather experience

11 More: F. A. P. Villar De Queiroz, Artistic Interdisciplinarity and La Fura Dels Baus 1979-1989, doctoral dissertation, Queen Mary College, University of London, London 2001, p. 35 and passim; K. Jungbluth, Co-Constructions in Multilingual Settings, in: Beyond Language Boundaries: Multimodal Use in Multilingual Contexts, eds. M. Fernández-Villanueva, K. Jungbluth, De Gruyter, Berlin, Boston 2016, p. 142.

12 J. Ostrowska, Living Theatre - od sztuki do polityki, Wydawnictwo „Kontekst”, Poznań 2005.

13 M. Sinclair, La Fura dels Baus - London Docklands, "NME" 1985, p. 7. 
a specific "performative gesture" that does not use the existing discourse, but forms it. ${ }^{14}$ In the show this is done by various elements related to a language, filled with mumbling cries and insignificant moans.

This is where a concept developed by Marcel Duchamp of "art coefficient"15 appeared in the works of the Catalonian group for the first time. It assumes active participation of a spectator, or rather almost a struggle between them and an artist, as a result of which raw material of the work is transformed. Therefore, spectators (or rather participants) of the show are intimidated by messages coming from hidden microphones, showered with sand by naked fureros and participate in an act of brutal devastation of the car with axes. Confronted with a lascivious act of destruction, a smile on the faces of young women and men from the audience disappears and transforms into a grimace of disbelief and fear. This is where Fura's aesthetics for the first time approaches a concept of forcing a spectator to participate through "aggressive attitude towards participants", ${ }^{16}$ typical of participatory art. These activities resemble French happenings of Jean-Jacques Lebel from the 1960s, described by Jean-Paul Sartre in the following way:

In France, Lebel exercises a certain sadism towards the public: the latter is stunned by flashing lights, unbearable noises, sprayed with diverse objects that are usually filthy, you have to go to these Happenings in old clothes... ${ }^{17}$

Similar observations are made by Carlus Padrissa (one of founders and the main artistic director of Fura, besides Àlex Ollé), who in interviews advises spectators to come to performances in loose comfortable clothes, so that they can escape and quickly react to actors' activities.

During performances from the 1980s, La Fura dels Baus deliberately gives up all forms of symbols on the stage. What is important is a new kind of verism, under the banner of literality and negation of a game, since everything that we can see in the performances of the Catalan group is as far from pretending as possible. Therefore, we deal with a double form of presence of the truth on the stage. Stage activities are not a play in a theatrical sense, gestures and struggles in a performative sense: actors do not reconstruct certain reactions and activi-

14 A. Sosnowska, J. Zielińska, Wprowadzenie | Performans teraz, "Obieg” 2017, no 4, http:// obieg.u-jazdowski.pl/numery/performans-teraz/performans-teraz [10.07.2018].

15 C. Tomkins, Duchamp: A Biography, Henry Holt and Company, New York 1998, p. 510.

16 C. Bishop, Artificial Hells. Participatory Art and the Politics of Spectatorship, Verso, LondonNew York 2012, p. 108.

17 J.-P. Sartre in: C. Bishop, Artificial Hells..., p. 100. 
ties, but create them. They do not metaphorise activities, but try to make them interpreted at the basic level. Secondly, the truth present on the stage is the truth of a message: it refers to real problems and real situations, though often removed from social consciousness. Therefore, we can recognize that the scope of this cruelty in the art of the Catalan group is wider than in the proposal of Antonin Artaud. It draws from assumptions of Panic Theatre of Fernando Arrabal and from theatrical, visual, film and literary experience of a Chilean, Alejandro Jodorowsky. This seems to be confirmed by the words of a theatre critic, José Sánchez Martínez:

Jodorowsky described his "holiday-performances" as a cross between what is Dionysian (Bacchanalian Revel before a Term) and cruel (Artaud's) with a large dose of circus aesthetics: "euphoria, humour and terror" added in order to remove a division between disciplines and a choice of an improvising model (derived from jazz). According to Jodorowsky, an abstract artist recreated violence "using colours, shapes and sizes". On the other hand, an artist of a concrete or panic imagination would "tear the material or crush a mechanism that can be identified without showing cruelty, but leaving traces of a real event. In short: the former expresses an act, the latter performs it". In the second part of Accions, men who had destroyed the car covered "los hombres de fango" with blue and black paint and chased them among the audience, throwing noodles. Then two men lowered themselves from the high on the cables and threw themselves on the large white canvas, breaking bags with red paint attached to their body to burst. In the end, the same men wrapped in transparent plastic and a third man in white performed the "body-image action" on the canvas. ${ }^{18}$

Although Fura's performances started with purely musical sequences, they exposed the corporeality: the actors treated their own skin as a large painting canvas or seemed to forget about its weaknesses. This show, close to body art, emphasized small but strong split between theatre, reality and life.

Similar elements of lasciviousness and aggression appeared in the play $\mathrm{Suz} / \mathrm{O} / \mathrm{Suz}$ (1985). Spectators were sprinkled with flour, thrown at with raw meat devoured by naked artists madly speeding in shop trolleys among terrified spectators. Participants of the performance thus acted: "as the medium or material of the work". 19

18 J. A. Sánchez Martínez, "Archivo Virtual Artes Escénicas” 2005, http://artesescenicas. uclm.es [5.06. 2018].

19 C. Bishop, Artificial Hells..., p. 5. 
Through extremely intense presence and dynamism of half-naked and naked actors, all Fura's performances from the 1980s and 1990s contain reference to the return to archaic, prediscursive corporality and spontaneous actions postulated by Artaud in the Theatre of Cruelty. ${ }^{20}$ Since a French director perceives a theatrical performance as a collective ritual act, which reveals collective unconsciousness and reaches the essence of humanity, theatre postulated by him is "affirmation of cruel and inevitable necessity". ${ }^{21}$

Let us also say that surprising as it may seem, hyperrealism in activities of La Fura dels Baus grows out of experience of the crisis of representation, appearing in the European theatre - as Peter Szondi noted - as early as at the end of the 19th century. A disaster of the theatre great metaphor, underlying the crisis of representation, makes its immanence, or an event which is called theatricality, is scattered in each of the acts and in representations themselves. In fact, what is analyzed today is weaknesses of a performance, while boundaries between theatricality and reality get blurred. In this way, theatre becomes more and more self-reflective, self-referential and self-aware, asking for its own definition and condition.

\section{Negation, shock and new technologies}

Deliberately eclectic poetics of the group became even more evident in the 1990s, when La Fura dels Baus began to be included among the most important theatrical groups in Europe. Performances staged by the "fureros" were then filled with "negation, disruption and antagonism" perceived as "viable [working] methods". ${ }^{22}$ Although their performances were still shocking for certain groups of spectators, they began to influence the international scene. Assuming that a performance success depends on whether it has the features (or appearance) of authenticity, and whether it is possible to create bonds between an actor and a spectator, so that the audience is a part of the performance, engaged into the action with which they identify, ${ }^{23}$ we can undoubtedly say that Fura's productions were successful. At the same time, the Catalan artists introduced significant changes to a theatrical work process. They mainly concerned weakening of a position of a human actor for the benefit of privileging experiences with the use of holographic and digital technology. A dividing line was

20 A. Artaud, Le théâtre de la cruauté, first print in "84" 1948, nos 5-6, pp. 121-130; reprint in: idem, Euvres complètes, Gallimard, Paris 1974, vol. XIII, pp. 105-118.

21 Quoted in: A. Artaud, Teatr Okrucieństwa, transl. B. Banasiak, http://bb.ph-f.org/przeklady/ artaud_teatr.pdf [07.07.2018].

22 C. Bishop, Artificial Hells ..., p. 189.

23 J. C. Alexander, Cultural Performance: Social Performance between Ritual and Strategy, "Sociological Theory" 2004, vol. 22, no 4, pp. 527-573. 
the year 1990, when the Noun project was created. It was the first performance using technologically advanced stage set-ups (with time, two-dimensional projections were replaced with 3D techniques and holography). Moreover, some stage solutions appeared under influence of chaos theory theses. Pornographic or scatological language was also in use.

This use of scandal and iconoclasm by the group was justifiable, even if due to the topics of violence and manipulation, or broadly understood politics, often taken up by them. The performances of La Fura dels Baus from the end of the 1990s became more and more "repressive", and spectators were still forced to stand in a crowd assembled at the performance, with no way out (escape) from dark quasi-theatrical space in which they were closed. There is a shocking confession associated with a mystical half-ununderstood experience from 2015 of one of the spectators participating in the performance titled Manes (directed by Pere Tantiñá), given by the "fureros" over 250 times since 1996 throughout Europe:

This was the most extreme and absolutely most mind blowing experience in my life. The most awesome, the most hysteric, most frightening, most surrealistic, most exiting experience - because this guys did use extreme visual picture, sound was extreme in a pitch black room. With changing strong smell and some did drink milk and did spit it out on the people. And a huge device with lots of spotlights got driving around very fast between the audience - so we had to move fast. All Senses got activated and all feeling who were possible at one time, did show up like waves. Sometimes running for life when huge eggs were rolling in between us and naked people showed up, or moving babies did lay on the floor, raw chicken meat did flying thru the air and people hanging like chickens in a slaughterhouse... The story was I guess about how it would be, when humans were chickens and chickens where humans and still acting like chickens or something like this.

You have to see this guys - you will never forget a extreme experience like this. Awesome and frightening at the same time... This really rocks, compared to everything else I have seen in the world. I saw them inside a old fortress in a room from the dark middelage. How they are outside - I can't tell. [the comment cited verbatim, all errors as in the original]. ${ }^{24}$

Aesthetic forms, especially the extensive scenography, overwhelmingly dominated over verbal message. Since scenography may stimulate various re-

24 La Fura dels Baus, Manes, https://www.youtube.com/watch?v=QrmHjvUfRaQ [6 July 2018]. 
presentative patterns in each viewer and, thus, create images that can turn into complete mental structures. It creates a network of relations with the audience space, a theatre building and even the entire external space surrounding the place of action. It is worth mentioning that many of Fura's performances take place in the free space, attracting unprepared audience to the whirl of extraordinary events.

In subsequent performances, spectators standing in the audience - which is a deliberate procedure - run away from electric carts in which the actors move or dodge cascades of water and sticky substances, in which the semi-naked or naked members of the group are repeatedly immersed. In MTM (1994), the pursuit of the effect brings artists to the sphere of theatrical shock, but the main goal is still the closest possible interaction with the audience. Risky as the comparison may seem, this longing for spectator's reaction, especially expressed on the stage, also with the help of complicated machinery, is influenced by the theatre developing in Max Reinhardt's tradition. According to José Sánchez Martínez:

This theatre sought to abolish the boundary, the fourth wall, which in naturalism separated what is artistic and real from fiction and its reporter. (...) autonomous Reinhardt's theatre may be considered a conceptual predecessor of the virtual space (...). ${ }^{25}$

Therefore, it is not surprising that theatre of the Catalan group, reaching for total techniques, engages and influences the audience, forcing them to react not only during the performance itself, but also after its finish. The group has come to Poland several times, always causing a scandal, changing local ideas about what is acceptable in the theatre, and, at the same time, arousing admiration and gaining a circle of devoted admirers - as if it was a revolutionary rock band. In 1996, the Catalan formation arrived at the Poznan Malta Festival with the MTM performance. It started with "hunting": the actors got among the spectators, catching a dozen or so people, who were forcefully undressed and placed on a platform. Then there was a lot of loud techno music, video projection, bodily rituals. The performance caused fear, but it involved, compelled and addicted. One of "addicts" was Marcin Liber, then an actor of the fringe theatre, Teatr Biuro Podróży, nowadays a director with his own significant achievements. His works were inspired by Fura for a long time. In 2010, Liber in his own theatrical performance entitled Mtm/La Fura Dels Baus remix $z$ pamięci returns to MTM, "remixing" the original and recalling what was most

25 J. A. Sánchez Martínez, Prácticas de lo real en la escena contemporánea, Visor Libros, Madrid 2007, p. 41. 
strongly recorded in his memory: "What did I remember? Bodies. A wall that divided us. And fear". ${ }^{26}$ It was fear and chaos that dominated the audience: "The performance was extremely brutal and although without it everything was under control, apparent chaos caused real physical fear in viewers". ${ }^{27}$

All the plays of the group from the 1980s and 1990s were clear examples of the theatre of audience active participation. As a theatre critic, Jerónimo López Mozo, recalls: "I will never forget a view of a woman who, in the midst of this orgy of destruction in the first of the abovementioned [Suz/O/Suz] hid away in the corner of the stage and remained motionless with her head hidden in her arms". ${ }^{28}$ So when discussing the role of the audience and its participation in Fura's performances, we should repeat after Bishop that an extremely important factor is "the historical fact of our ineradicable presence requires an analysis of the politics of spectatorship, even - and especially - when participatory art wishes to disavow this". ${ }^{29}$ At the same time, although participation in performances of La Fura dels Baus becomes for some people a mystical or even ritual experience, we cannot perceive its performances as a theatre for the elites. Rather, like Reinhardt's "theatre for Five Thousand" - it is a theatre for masses, a folk theatre, sometimes close to historical, mainly post-war search of Jean Vilar, according to whom the entire theatre should belong to everyone and be intended for everyone. Therefore, in theatre of La Fura dels Baus aesthetic forms become unity, and both a stage and the audience may be recognized as the theatrical space. It results from the fact that a theatrical event takes place everywhere. There is no, either physically or symbolically, a ramp that would separate two realities. La Fura dels Baus uses its surroundings as a stage, where it places an active spectator, who becomes the next actor. It is their reaction and commitment - in accordance with performative theories - that complements a "proper" performance. Theatre is no longer limited to experience on the stage and is not dependent on director's guidelines: it penetrates subsequent places of the theatre space, transforming everything around into theatre. In this new, larger space new threads develop and give birth to new conflicts - but with greater intensity, longer duration and greater drama. This way of inducing the expected catharsis is accompanied by the use of great effects to awaken a new type of emotions in the audience.

26 Komuna Warszawa, Marcin Liber, Mtm/La Fura Dels Baus. remix z pamięci, http://komuna. warszawa.pl/2010/06/15/marcin-liber-mtmla-fura-dels-baus-remix-z-pamieci/ [07.07.2018].

27 J. López Mozo, Boris Godunov. La Fura Domesticada, “Crítica Teatro", http://www.madridteatro.eu/teatr/teatro/2008/teatro360.htm [08.07.2018].

Ibid.

29 C. Bishop, Artificial Hells ..., p. 9. 


\section{Cruelty techniques in the art of La Fura dels Baus}

La Fura dels Baus often uses violence, referring to the theory of Antonin Artaud. However, this is not about simply transferring theses and postulates of the author of the Theatre of Cruelty, but about their new interpretation, about creating a theory of theatre of violence. In the essay, The Theater and Its Double, Artaud writes that confusion is the sign of his era (yet, this remark can also be referred to modern days) and the main source of this confusion was the split between words and things. The signs no longer represent what they really meant, and therefore, in the context in which they function, they cancel each other out. Theatre, on the one hand, uses these means, on the other - hides them using aesthetic games.

Especially in the first performances, the Catalan group challenged more than just the idea of mimetic theatre. Although - as has been mentioned earlier - La Fura dels Baus was inspired by theories of great masters (Artaud, Meyerhold, Barba), the artists constantly emphasized the role of total rebellion, characterized, among others, by iconoclasm and disrespect for spectators' expectations and theatre theoreticians. Interestingly, however, there were no postulates aiming at undermining the value of classics of the twentieth-century avant-garde. Fura betrayed former ideals rather than denying or ignoring them. It deconstructed and destroyed rather than attempting to protect this great legacy. In addition, when analyzing a text layer, we may say that we deal with recycling of old artistic works (this is evident, for example, in numerous references to famous operas from which music and libretto were borrowed: Turandot, Siegfried, Tannhäuser, Le Grand Macabre). And also that there is a specific détournement (hijacking) understood, after Hal Foster and Guy Debor, as "the reuse of preexisting artistic elements in a new ensemble". ${ }^{30}$ This is the character of the most shocking performance of the "fureros" - XXX (premiered in 2001) directed by Àlex Ollé and Carlos Padrissa.

It is a production based on the performance by Marquis de Sade from 1795 Philosophy in a Boudoir. ${ }^{31}$ The original version presents a full catalogue of deviations, ranging from a description of the simplest and the most "innocent" to the most sophisticated and brutal ones. ${ }^{32}$ Except for the condensed content, as a result of the use of the form of dialogue, the whole is lively and seems to be an authentic experience. Thus, even during De Sade's life, there were attempts

30 H. Foster, The Return of the Real: The Avant-garde at the End of the Century, MIT Press, Cambridge-London 1996, p. 198.

31 D. A. F. de Sade, Filozofia w buduarze albo Libertyńscy nauczyciele, Dialogi przeznaczone do edukacji mtodych dziewczat, transl. M. Skrzypek, Szumacher, Kielce 1995.

32 Ibid., pp. 5-9. 
to read the work as a guidebook of sexual education for libertines..$^{33}$ The performance by the "fureros" was also going to have similarly "educational" character, which was mentioned by Padrissa in an interview given to Belen Ginart. ${ }^{34}$ Fura used the Marquis de Sade's work, presenting its extracts in form of the text on the screens (the adaptation was made by a somewhat scandalous Italian writer, Aldo Nove) ${ }^{35}$ However, the story presented in $X X X$ is set in the present times. For two hours, spectators watch an innocent girl, Eugénie, who is perverted by three libertine figures: a retired porn star, her cruel brother and a perverse intellectual, Dolmancé (alter ego of de Sade). Since the actors had cameras attached to their bodies, and the recorded images were displayed on large screens placed in the background, the sense of intense audience participation in the pornographic spectacle was enormous. Therefore, the spectators were instructed that if the message was too intense, they should call artists' mobile phones to make it softer. The screens at the back of the stage showed pornographic films and images from the Internet as well as the aforementioned de Sade's texts. In directors' assumptions, fragments of texts were going to serve the purpose of structuring and linking subsequent scenes of a very pornographic nature. However, in $X X X$, La Fura goes a step further. Here, actors' dialogues interact with the website format projections, filled with movies, sounds, graphics and links, similar to those used when browsing the web. These projections are intended not only to synthesize and strengthen certain elements of the piece of art, but also to dynamize and radically update the text written by one of the most expressive and controversial minds of the 18th century. ${ }^{36}$ During the performance, the audience could use their own mobile phones to send short messages with descriptions of their own sexual fantasies caused by the performance. Immediately after sending, the messages appeared on the screens on the stage. British BBC described the performance as "shocking" and the most sexual [performance] ever staged in the UK. ${ }^{37}$ While the Britain's tabloid press wondered whether it was still art or pornography: 'Art? This is nothing more than porn' ("Daily Mail”), 'Sex on Stage Storm: Raunchiest show ever hits UK' ("Daily Star”), 'XXX: Is this play art or porn?' ("Daily Mirror"), 'XXX-Rated: Anger at hardcore sex act in shock new play' ("The Sun”). ${ }^{38}$

33 Ibid., p. 5.

34 B. Ginart, La Fura dels Baus ensaya la pornografía como forma de provocación en 'XXX', "El País” 2001, https://elpais.com/diario/2001/08/25/revistaverano/998690401_850215.html [10.07.2018].

35 Ibid

36 La Fura dels Baus, XXX, https://www.lafura.com/obras/xxx/ [12 July 2018].

37 E. Diaz Sanmartin, La Fura Dels Baus: From Post-Modern Theatre to Post-Human Theatre, "Cultural Hybridity" 2012, https://irvine-cct.wikispaces.com/EDiazSanmartin [12.07.2018].

38 Quoted in: R. Mock, La Fura dels Baus's XXX: Deviant Textualities and The Formless, in: Sensualities/Textualities and Technologies. Writings of the Body in 21st Century Performance, eds. S. Broadhurst, J. Machon, Palgrave Macmilian, Basingstoke [England], New York 2009, p. 132. 
It is in this play that La Fura dels Baus stands out, showing and, at the same time, crossing the boundary between traditional theatre and digital theatre. It is here, at the junction of a traditional box stage and an experimental scene, that the theatre of the group and its theatrical proposals become a part of the contemporary problem of theatrical postmodernity. It is mainly achieved, as we have already mentioned, through introduction of video, holographic images, projections and a variety of aesthetic interventions, which appear more and more often in new stage and theatre proposals of the contemporary scene and become a part of permanent practices of La Fura dels Baus. Since the group easily uses post-modern theatre techniques, its realisations include pastiche, collage and syncretism. Its performances express a critical look at cruelty, but this time - at technological cruelty, born along with new technologies and communicated with them. It is digital cruelty and, therefore, cruelty of our times. Artaud's theatre of cruelty was meant to demolish contemporary stage and theatre model (which could be described as "action theatre"). ${ }^{39}$ Today, this model has to change, because everyday reality has crossed the boundaries of a traditional theatrical medium.

Experiences with digital media were later continued by the group during such productions as Boris Godunov (2008) or Degustación de Titus Andrónicus (2011), as well as in the intriguing concept of the group from the beginning of the 21st century - Naumon ship. Naumon is an over 60-meter long, worn-out icebreaker purchased (in 2003) as an unusable recycling product. The group intended it to become embodiment of the intriguing thesis that "sailing is also culture". The ship with the actors is a stage (but also a trap - "micro-utopias", known from the concept of relational aesthetics), floating between the ports of Barcelona, Sardinia, Portugal, Beirut, Taipei, Newcastle, Mexico and Haifa. Naumon has become a real "portable" Performing Arts Centre for the group carrying finished artistic, educational and cultural projects in renovated holds. Permanent cranes, jibs and nets as well as zepellins are permanently attached to the board; all these elements are used in staging spatial performances filled with light, music and movement. Some of the rooms have been transferred into cabins, others to a café and a buffet. Inside, under the deck, there is a stage, where performances for a group of 500 spectators, so-called Matrias, are played. At the same time, when the ship moors to the port, crowds of people gathering on the quay, take part in technologically sophisticated performances of the group, known as Naumaquias; and when the play takes place on city streets, they participate in Terramaquias. This is real entering of the theatre into everyday life (taking art to the streets), excessively meeting a postulate of

39 R. Zaporah, Action Theatre: the improvisation of presence, North Atlantic Books, Berkeley 1995. 
an artist, Rirkrit Tiravanija, indicating that "a large number of people" must participate in the artistic event. In their activities involving the Naumon ship, the group diverges from any propaganda of democracy in the journalistic style, creating "an open setting where a dialogue with a spectator takes place and where a spectator is encouraged to act in public space". ${ }^{40}$

It is also worth paying attention to the fact that broadly understood media activities of Fura may also be included in the trend of convergence culture, ${ }^{41}$, not only because of the use of modern digital technologies supporting their performances, but also due to creation of digital versions with recordings of their own theatrical performances, CDs and streaming with music and presentation of videos from performances on social networks, especially on the YouTube channel. We should note the latter medium contributes to shaping of so-called snack culture. This term refers to the characteristics of YouTube as a place of defragmentation of content, described by Jan van Dijk. ${ }^{42}$ Snack culture is a term that perfectly reflects both a form of messages available on the portal (short videos up to ten minutes) and the way of dealing with these materials (with a focus on fast and intense experience). When we immerse ourselves in Fura's films, the group's productions will appear fast, fragmentary, aggressive and techno-like, which is emphasized by electronic music, with a uniform regular rhythm in four fourths, perfectly synchronized with the modern world.

$* * *$

The creative activity of La Fura dels Baus is undoubtedly an example of transtheatricality and the search for new values in art. To explain this, we should remember that a starting point in a conventionally understood theatre is a real event (everyday life), which is transformed into a theatrical event, while in many contemporary theatrical attempts, on the contrary, there are attempts to turn a theatrical event into a real event. Therefore, on stage, the theatre evolves into life and life evolves into theatre, and this mechanism, specifically the clash of these two concepts is a source of transtheatricality. One theatricality is linked to another, creating a maze with forked paths. Art approaches with the order to repair the society because other social solutions have failed. This allows us to say that theatre and theatricality of La Fura dels Baus become virtual and at the same time hyper-real theatre, which in turn leads to hypertheatricality, and everything in this theatre is hyper-connected in many different ways, while sensual immediacy appears to be as a potential place of de-alienation.

\footnotetext{
40 N. Bourriaud, Estetyka..., p. 23.

41 H. Jenkins, Convergence Culture: Where Old and New Media Collide, New York and London 2006.

42 J. van Dijk, The Network Society: Social Aspects of New Media, SAGE, London 2005.
} 


\section{BIBLIOGRAPHY}

Alexander Jeffrey C. (2004) Cultural Performance: Social Performance between Ritual and Strategy, "Sociological Theory", vol. 22, no 4, pp. 527-573.

Artaud Antonin (1948) Le théâtre de la cruauté, “84”, nos 5-6, pp. 121-130.

Artaud Antonin (1974) Euvres complètes, vol. XIII, Paris: Gallimard, pp. 105-118.

Artaud Antonin (n.d.) Teatr Okrucieństwa, transl. B. Banasiak, http://bb.ph-f.org/przeklady/artaud_teatr.pdf [07.07.2018].

Bishop Clair (2012) C. Bishop, Artificial Hells. Participatory Art and the Politics of Spectatorship, London-New York: Verso.

Bourriaud Nicolas (2012) Estetyka relacyjna, transl. Ł. Białkowski, Kraków: MOCAK.

Debord Guy (2006) Społeczeństwo spektaklu oraz Rozważania o społeczeństwie spektaklu, transl. M. Kwaterko, Warszawa: Państwowy Instytut Wydawniczy.

Diaz Sanmartin Elisabet (2012) La Fura Dels Baus: From Post-Modern Theatre to Post-Human Theatre, "Cultural Hybridity", https://irvine-cct.wikispaces.com/EDiazSanmartin [12.07.2018].

Dijk van Jan (2005) The Network Society: Social Aspects of New Media, London: SAGE.

Ginart Belen (2001) La Fura dels Baus ensaya la pornografía como forma de provocación en 'XXX', "El País”, https://elpais.com/diario/2001/08/25/revistaverano/998690401_850215.html [10.07.2018].

Hal Foster (1996) The Return of the Real: The Avant-garde at the End of the Century, CambridgeLondon: MIT Press.

Jenkins Henry (2006) Convergence Culture: Where Old and New Media Collide, New York and London: NYU Press.

Jungbluth Konstanze (2016) Co-Constructions in Multilingual Settings, [in:] M. FernándezVillanueva, K. Jungbluth, eds., Beyond Language Boundaries: Multimodal Use in Multilingual Contexts. Berlin, Boston: De Gruyter, pp. 137-152.

Keil Marta (2015) Do czego jest nam dzisiaj potrzebna krytyka instytucjonalna?, "Polish Theatre Journal", nos 1-2, pp. 1-9.

Kluszczyński Ryszard W. (1997) Awangarda - rozważania teoretyczne, Łódź: Wydawnictwo Uniwersytetu Lódzkiego.

Komuna Warszawa (n.d.) Marcin Liber, Mtm/La Fura Dels Baus. remix z pamięci, http://komuna. warszawa.pl/2010/06/15/marcin-liber-mtmla-fura-dels-baus-remix-z-pamieci/ [07.07.2018].

Kuspit Donald (1993) The Cult of the Avant-Garde Artist, Cambridge: Cambridge University Press. 
LaFura dels Baus(n.d.) Manes, https://www.youtube.com/watch?v=QrmHjvUfRaQ [06.07.2018].

La Fura dels Baus (n.d.) $X X X$, https://www.lafura.com/obras/xxx/ [12.07.2018].

López Mozo Jerónimo (n.d.) Boris Godunov. La Fura Domesticada, "Crítica Teatro", http://www. madridteatro.eu/teatr/teatro/2008/teatro360.htm [08.07.2018].

Martínez José (1994) La Fura dels Baus, “La Nueva Espańa”, p. 38.

Mock Roberta (2009) La Fura dels Baus's XXX: Deviant Textualities and The Formless, [in:] S. Broadhurst, J. Machon, eds., Sensualities/Textualities and Technologies. Writings of the Body in 21st Century Performance. Basingstoke [England], New York: Palgrave Macmilian, pp. 132-145.

Ostrowska Joanna (2005) Living Theatre - od sztuki do polityki, Poznań: Wydawnictwo „Kontekst”.

Sade de Donatien A. F. (1995) Filozofia w buduarze albo Libertyńscy nauczyciele, Dialogi przeznaczone do edukacji młodych dziewczat, transl. M. Skrzypek, Kielce: Szumacher.

Sánchez Martínez José A. (2005) “Archivo Virtual Artes Escénicas”, http://artesescenicas.uclm. es [5.06.2018].

Sánchez Martínez José A. (2007) Prácticas de lo real en la escena contemporánea, Madrid: Visor Libros.

Sinclair Mick (1985) La Fura dels Baus - London Docklands, "NME“, p. 7.

Sosnowska Agnieszka, Zielińska Joanna (2017) Wprowadzenie | Performans teraz, "Obieg”, no 4, http://obieg.u-jazdowski.pl/numery/performans-teraz/performans-teraz [10.07.2018].

Tomkins Calvin (1998) Duchamp: A Biography, New York: Henry Holt and Company.

Villar De Queiroz Fernando A. P. (2001) Artistic Interdisciplinarity and La Fura Dels Baus 1979-1989, doctoral dissertation, London: Queen Mary College, University of London.

Zaporah Ruth (1995) Action Theatre: the improvisation of presence, Berkley: North Atlantic Books.

Zmyślony Iwo (n.d.) Lekkie rozczarowanie. Rozmowa z Claire Bishop, “dwutygodnik.com”, http:// www.dwutygodnik.com/artykul/6460-lekkie-rozczarowanie.html [10.06.2018]. 


\section{SZTUKA PARTYCYPACYJNA, NOWE MEDIA I KULTURA KONWERGENCJI NA PRZYKŁADZIE GRUPY LA FURA DELS BAUS (streszczenie)}

Artykuł jest próbą przedstawienia różnych kategorii działań związanych ze sztuką partycypacyjną, jakie możemy odnaleźć w bogatej twórczości artystycznej katalońskiej grupy La Fura dels Baus. Od momentu gdy zespół powstaje w 1979 r. prezentuje bardzo rozmaite formy: spektakle plenerowe, przedstawienia dramatyczne, opery, performansy. Operuje technikami typowo teatralnymi, akcentując zwłaszcza doświadczenia i eksperymenty quasi-religijne wywodzące się z mitycznej prehistorii sztuki sceny i nowsze techniki grupowe (happening, techniki wypracowane przez zespoły okresu kontestacji). Omówione zostały takie widowiska jak: Accions (1983), Suz/O/Suz (1985), Noun (1990), Manes i MTM (oba 1996) oraz XXX (2001). Przedmiotem szczególnych rozważań jest, przejęcie i dostosowanie Artaudowskiego konceptu „teatru okrucieństwa”, w odniesieniu do działań grupy, które jednocześnie są analizowane w perspektywie wymuszonej środkami artystycznymi partycypacji publiczności w spektaklach.

Słowa kluczowe: La Fura dels Baus, partycypacja, teatr okrucieństwa, spektakl, publiczność. 